\title{
PEMBUATAN DAN KUALITAS KARTON DARI CAMPURAN PULP TANDAN KOSONG KELAPA SAWIT DAN SLUDGE INDUSTRI KERTAS
}

\author{
(Manufacture and Qualities of Paperboard from the Mixture of \\ Empty Oil-Palm Bunches Pulp and Paper-Mill Sludge)
}

\author{
Oleh/By :
}

Han Roliadi \& Ridwan A. Pasaribu ${ }^{1)}$

\begin{abstract}
Small-scale paperboard industries in Indonesia are currently faced with the difficulty in procurement continuity of fibrous raw material (particularly pulp and waste paper). On the other hand, empty oil-palm bunches (EOPB) are abundant as waste from palm-oil processing and those ligno-cellulosic fiber stuffs have not been utilized effectively, bence suggesting theirpotential use for thosepaperboard industries.

Related with such, the EOPB after being chipped has been experimentally pulped using hot soda semi-chemical process in the semi-pilot scale closed (pressurized) digester designed by the Center for Forest Product Research and Development, Bogor employing the cooking conditions: $10 \%$ alkali $(\mathrm{NaOH})$ concentration, 1:5.5 ratio of EOPB chips to cooking liquor, maximum temperature at $120^{\circ} \mathrm{C}$ kept for 2 hours under $1.2-1.5$ atmosphere pressure. The process afforded the EOPB pulpyield at $60.17 \%$, kappa number 38.17, and alkali consumption $9.81 \%$. Further, paperboard sheet was formed in a small-scale paperboard industry, from the mixture of $50 \%$ EOPB pulp and $50 \%$ paper-mill sludge; and from $100 \%$ EOPB pulp, each incorporating the additives (i.e. $5 \%$ kaolin filler, $2 \%$ alum retention, $4 \%$ tapioca binder, and $2 \%$ rosin size).

Physical properties of paperboard from 100\% EOPB pulp and from its mixture with paper-mill sludge $150 \%$ : $50 \%$, respectively) were better than those produced by the small-scale industry traditionally using the mixture of $50 \%$ sludge and 50\% waste paper without additives. This suggests the prospective use of EOPB pulp mixed with sludge, as alternative/substitute raw material in the paperboard industry that uses wastepaper.
\end{abstract}

Keywords: Empty oil-palm bunches (EOPB), pulp, paperboard, and small-scale paperboard industry

\begin{abstract}
ABSTRAK
Industri karton skala kecil saat ini mengalami kesulitan kontinuitas pasokan bahan baku (khususnya pulp dan kertas bekas). Limbah industri pengolahan minyak kelapa sawit dalam bentuk tandan kosong kelapa sawit (TKKS) sebagai bahan serat berligno selulosa berlimpah jumlahnya dan belum banyak dimanfaatkan, sehingga berindikasi pemanfaatannya sebagai bahan baku industri karton.
\end{abstract}

${ }^{1)}$ Peneliti pada Pusat Penelitian dan Pengembangan Hasil Hutan, Bogor 
TKKS sesudah dijadikan serpih, diolah menjadi pulp menggunakan proses semikimia soda panas tertutup pada ketel pemasak skala semi-pilot hasil rekayasa Pusat Litbang Hasil Hutan (Bogor) pada kondisi pemasakan: konsentrasi alkali $(\mathrm{NaOH}) 10 \%$, nilai banding serpih TKKS dengan larutan pemasak 1:5.5, dan waktu pemasakan 2 jam pada suhu maksimum $120 \mathrm{oC}$ dan tekanan 1,2 - 1,5 atmosfir. Rata-rata rendemen pulp TKKS yang diperoleh 60,17\%, bilangan kappa 38,17, dan konsumsi alkali 9,81\%. Lembaran karton dibentuk dari campuran pulp TKKS 50\% dan sludge industri kertas 50\%; dan dari pulp TKKS 100\%, masing-masing dengan penambahan bahan aditif (kaolin 5\%, alum 2\%, tapioka $4 \%$, dan rosin size $2 \%$ ).

Sifat fisik karton asal pulp TKKS $100 \%$ dan asal campurannya dengan sludge industri kertas $(50 \%$ : 50\%) lebih tinggi dari pada karton produksi industri rakyat (dari campuran kertas bekas 50\% dan sludge $50 \%$, (tetapi tanpa bahan aditif). Hal ini mengisyaratkan prospek penggunaan pulp TKKS yang dicampur dengan sludge, sebagai bahan baku altermatif/pengganti pada industri karton yang menggunakan kertas bekas.

Kata kunci: Tandan kosong kelapa sawit (TKKS), pulp, karton, dan industri karton rakyat

\section{PENDAHULUAN}

Industri karton skala kecil pada saat ini umumnya mengalami kesulitan mendapatkan bahan baku berupa pulp dan kertas bekas dalam jumlah yang cukup dan harga yang dapat diterima oleh industri kecil tersebut. Salah satu upaya yang dilakukan oleh industri untuk mengatasi masalah tersebut adalah dengan cara memperoleh karton yang menggunakan sludge dari limbah industri pulp dan kertas sebagai bahan baku utama dan kertas bekas sebagai pencampur. Ternyata kualitas karton yang diproduksi masih rendah, karena serat kertas bekas dan sludge berkualitas rendah dan serat sludge sangat hidrokopis, sehingga karton yang diproduksi mengandung air cukup besar dan tidak kaku (Anonim, 1994). Akibatnya produksi karton skala kecil ini tidak dapat memenuhi permintaan kualitas karton dari beberapa produsen produk jadi skala kecil atau rumah tangga, seperti produsen bukubuku pelajaran, sepatu, tas, pakaian jadi, pemintal benang dan tekstil.

Salah satu upaya yang dapat dilakukan Pusat Penelitian dan Pengembangan Hasil Hutan $(\mathrm{P} 3 \mathrm{HH})$ Bogor, adalah mencari dan mendapatkan bahan berserat lignoselulosa yang dapat dijadikan bahan baku karton, berpotensi cukup besar dan belum banyak dimanfaatkan secara komersial. Bahan berserat lignoselulosa yang diharapkan dapat mendukung upaya tersebut adalah tandan kosong kelapa sawit (TKKS) yang merupakan limbah dari industri pengolahan minyak kelapa sawit dan sludge yang merupakan limbah dari industri pulp dan kertas. Direktorat Jenderal Perkebunan menyatakan bahwa pabrik pengolahan minyak kelapa sawit yang berkapasitas 30 ton minyak kelapa sawit (crude palm oil atau CPO) menghasilkan 30 - 35 ton TKKS (Anonim, 1998a dan 1998b). Terkait dengan hal tersebut, data terakhir menunjukkan bahwa produksi CPO Indonesia pada tahun 2005 mencapai 13,3 juta ton (Anonim, 2006), yang berarti menghasilkan TKKS sebanyak 13,3 - 15,5 juta ton. TKKS saat ini hanya digunakan sebagai bahan bakar ketel pabrik minyak kelapa sawit, kompos, dan pupuk kalium. Namun pemanfaatan ini belum memberikan nilai tambah yang optimal.

Rina, dkk (2002) menyatakan bahwa sludge atau limbah padat organik yang dihasilkan dari industri pulp dan kertas merupakan sekitar 3 - 4\% dari produksi ril pulp atau kertas. Apabila produksi riil pulp sebesar 5,5 juta ton/tahun (Anonim, 2006), maka sludge yang dihasilkan industri pulp sekitar 0,16 - 0,21 juta ton/tahun atau 500 - 700 ton/hari. Sedangkan 
dari industri kertas dengan produksi ril sebesar 8,21 juta ton/tahun akan menghasilkan sludge sekitar 0,25 - 0,33 juta ton/tahun atau sekitar 800 - 1100 ton/hari.

Adanya limbah TKKS yang berpotensi cukup tinggi dan pemanfaatannya belum memberikan nilai tambah yang optimal dan demikian pula sludge industri pulp/kertas, serta sulitnya industri karton rakyat berskala kecil untuk mendapatkan pulp yang cocok untuk karton dengan harga yang terjangkau, maka Pusat Penelitian dan Pengembangan Hasil Hutan (P3HH, Bogor) telah berinisiatif mencoba pembuatan pulp dari TKKS untuk karton menggunakan ketel pemasak skala semi pilot hasil rekayasa P3HH. Selanjutnya untuk mengetahui cocok tidaknya pulp TKKS tersebut untuk digunakan sebagai bahan baku karton pada skala industri kecil, maka telah dilakukan percobaan pembuatan lembaran karton pada industri karton terkait dengan atau tanpa dicampur sludge industri kertas dan kertas bekas, masing-masing dengan penambahan aditif yaitu: kaolin 5\%, alum 2\%, dan perekat tapioka 4\% (Roliadi dan Pasaribu, 2004).

Hasil penelitian menunjukkan bahwa sifat lembaran karton hasil percobaan dari pulp TKKS 100\%; dan dari campuran pulp TKKS (50\%) dengan sludge (25\%) dan kertas bekas (25\%), masing-masing dengan penambahan bahan aditif, lebih baik (lebih tinggi) dari pada karton produksi industri rakyat (skala kecil) yang menggunakan bahan baku campuran sludge $(50 \%)$ dan kertas bekas (50\%), tetapi tanpa bahan aditif. Selanjutnya dibandingkan dengan kualitas karton komersial dan persyaratan kualitas jenis chipboard, sifat lembaran karton hasil percobaan tersebut memenuhi syarat, kecuali dalam hal indeks tarik, indeks pecah, dan indeks sobek. Untuk memperbaiki sifat tersebut, bahan sizing rosin soap telah digunakan dalam percobaan pembuatan karton skala kecil dari pulp TKKS dan campurannya dengan sludge industri kertas.

\section{METODOLOGI}

\section{A. Lokasi Penelitian}

Percobaan pembuatan pulp dari TKKS dilakukan di Laboratorium Pengolahan Kimia (P3HH, Bogor). Sedangkan pembentukan lembaran karton dari pulp tersebut dilakukan di industri karton rakyat (PT “DS”), Kabupaten Kebumen, Jawa Tengah.

\section{B. Bahan dan Peralatan}

Bahan baku penelitian adalah tandan kosong kelapa sawit (TKKS) yang berasal dari limbah industri pengolahan minyak kelapa sawit (PT Kertajaya) yang terdapat di daerah Malingping (Pandeglang), Propinsi Banten. Bahan kimia yang digunakan untuk analisa sifat pengolahan pulp (konsumsi alkali dan bilangan kappa) adalah barium chlorida $\left(\mathrm{BaCl}_{2}\right)$, asam chlorida $(\mathrm{HCl})$ 0,1 $\mathrm{N}$ dan indikator fenolthalein, kalium permanganat $\left(\mathrm{KMnO}_{4}\right) 0,1 \mathrm{~N}$, asam sulfat $\left(\mathrm{H}_{2} \mathrm{SO}_{4}\right)$, kalium iodida $(\mathrm{KI})$, natrium tiosulfat $\left(\mathrm{Na}_{2} \mathrm{~S}_{2} \mathrm{O}_{3}\right) 0,2 \mathrm{~N}$, dan indikator kanji. Bahan kimia pemasak serpih TKKS yang digunakan adalah soda api $(\mathrm{NaOH})$, sedangkan untuk pembentukan lembaran karton digunakan bahan pengisi kaolin, bahan retensi alum sulfat dan bahan perekat tapioka.

Peralatan yang digunakan untuk produksi pulp karton dari TKKS adalah ketel pemasak hasil rekayasa P3HH (Bogor) yang dipanaskan dengan kompor minyak tanah bertekanan, bak pencuci serpih hasil pemasakan, hollander beater, dan stone refiner untuk penyempurnaan 
pemisahan serat. Sedangkan peralatan yang digunakan untuk pembentukan lembaran karton terdapat pada industri karton rakyat di Kebumen (Jawa Tengah) mencakup: hollander beater, stock chest, mesin kertas fourdrinier, pengering lembaran karton menggunakan sinar matahari, calendering untuk pengepresan lembaran karton, dan alat pemotong dan pengepakan lembaran karton.

Peralatan yang digunakan untuk pengujian sifat fisik lembaran karton adalah tearing tester untuk menetapkan indeks sobek, bursting tester untuk menetapkan indeks pecah, tensile tester untuk menetapkan indeks tarik, dan ring crush (ketahanan lingkar) tester.

\section{Prosedur Kerja}

\section{Pembuatan pulp TKKS}

\section{a. Penyiapan serpih TKKS}

TKKS dibersihkan dengan cara pencucian menggunakan air dingin (suhu kamar) untuk membersihkan TKKS dari kotoran berupa pasir, tanah, kulit buah kelapa sawit. Selanjutnya TKKS hasil pencucian dijemur sampai mencapai kadar air sekitar 40 - 50\%. Kemudian TKKS hasil penjemuran dibelah dengan golok dan dijadikan serpih yang berukuran panjang sekitar 5 $\mathrm{cm}$, lebar $4 \mathrm{~cm}$ dan tebal sekitar $1-2 \mathrm{~cm}$.

\section{b. Pemasakan serpih TKKS menjadi pulp}

Pembuatan pulp TKKS dilakukan dengan proses semi-kimia soda panas tertutup. Serpih dimasak dalam ketel pemasak hasil rekayasa P3HH (Bogor) yang dipanaskan dengan kompor minyak tanah bertekanan di atas satu atmosfir. Ketel pemasak berkapasitas $50 \mathrm{~kg}$ serpih berat kering oven atau sekitar $125 \mathrm{~kg}$ serpih berat basah dan bersifat statik. Pemasakan serpih TKKS dilakukan pada konsentrasi $\mathrm{NaOH} 10 \%$ selama 2 jam pada suhu pemasakan maksimum $120^{\circ} \mathrm{C}$. Nilai banding serpih TKKS terhadap larutan pemasak adalah $1: 5,5$ dan tekanan sekitar 1,2 - 1,5 atmosfer.

Selesai pemasakan serpih lunak TKKS dipisahkan dari larutan pemasak, selanjutnya serpih dicuci sampai bebas dari sisa larutan pemasak. Serpih lunak TKKS hasil pencucian diberi perlakuan mekanis sehingga terurai menjadi serat-serat terpisah (defiberasi) dalam hollander beater pada konsistensi 2,0 - 2,5\%. Penguraian serat tersebut dilanjutkan pada stone refiner yang diulang sebanyak 2 kali hingga mencapai derajat kehalusan pulp untuk karton sekitar $400 \mathrm{ml} \mathrm{CSF}$ (Canadian Standard Freeness). Karena kapasitas holander beater dan stone refiner relatif kecil $( \pm 1 \mathrm{~kg})$ dibandingkan dengan kapasitas ketel pemasak (125 kg serpih TKKS basah), maka penggilingan dalam hollander beater dan stone refiner dilakukan secara bertahap (batch), dan rata-rata waktu giling setiap batch tersebut dicatat. Seluruh pulp TKKS yang telah digiling dikurangi kadar airnya pada alat sentrifugal, lalu ditetapkan rendemennya dan selanjutnya siap dibentuk menjadi karton.

\section{c. Pengujian sifat pengolahan pulp TKKS}

Sifat pengolahan pulp TKKS yang diamati adalah rendemen pulp, bilangan kappa pulp, konsumsi alkali, dan rata-rata total waktu giling pulp TKKS untuk mencapai derajat kehalusan $400 \mathrm{ml} \mathrm{CSF}$, menurut prosedur dan standar TAPPI (Anonim, 1972 dan 1983). 


\section{Pembuatan lembaran karton}

\section{a. Pembentukan lembaran karton}

Pulp TKKS dengan derajat kehalusan sekitar $400 \mathrm{ml}$ CSF tersebut dimasukkan kedalam hollander beater milik industri karton rakyat, lalu ditambahkan sludge industri kertas, sedemikian rupa hingga proporsi campurannya berturut-turut 50\% (pulp TKKS) dan 50\% (sludge), selanjutnya diencerkan hingga mencapai konsistensi sekitar 4 - 5\%. Campuran pulp TKKS dan sludge tersebut diaduk disirkulasi dalam holander beater sehingga tercerai berai dan terbentuk campuran homogen. Selanjutnya, campuran tersebut diberi bahan aditif (pengisi kaolin, retensi alum, perekat tapioka, dan rosin size), masing-masing sebanyak 5, 2, 4, dan 2\% terhadap total berat kering bahan serat dalam holander beater. Ramuan campuran tersebut terus diaduk/disirkulasi sehingga terjadi lagi campuran yang homogen. Sesudahnya, ramuan tersebut siap dibentuk lembaran karton pada mesin kertas tipe fourdrinier. Lembaran basah yang terbentuk dipotong secara tegak lurus terhadap arah pergerakan lembaran pada mesin kertas tersebut setiap mencapai panjang sekitar $100 \mathrm{~cm}$, lalu dijemur di bawah sinar matahari hingga kadar airnya mencapai 10\%. Setelah kering, lembaran tersebut lalu ditumpuk, masing-masing dicalendering, di press, dan dikemas. Karton yang terbentuk diharapkan mencapai target gramatur 300 - 350 gram per $\mathrm{m}^{2}$.

Di samping itu dibentuk pula lembaran karton dari pulp TKKS murni (100\%) dalam bolander beater milik industri karton rakyat, lalu diberi bahan aditif berupa kaolin (5\%), alum $(2 \%)$, tapioka $(4 \%)$, dan rosin size $(2 \%)$. Prosedur pembentukan lembaran karton sama seperti pada pembentukan karton dari campuran pulp TKKS $50 \%$ dan sludge $50 \%$, berikut bahan aditif. Target gramatur karton dari pulp TKKS murni juga sebesar 300-350 gram per $\mathrm{m}^{2}$.

Selanjutnya, sebagai pembanding terhadap baik lembaran karton asal pulp TKKS 100\% maupun asal campurannya (pulp TKKS 50\% dan sludge 50\%), digunakan kertas karton yang diproduksi oleh pabrik karton rakyat yang menggunakan bahan baku 50\% kertas bekas dan $50 \%$ sludge, tanpa bahan aditif.

\section{b. Pengujian sifat fisik lembaran karton}

Sifat fisik lembaran karton yang diamati meliputi indeks sobek menurut SNI 0435-89 (Anonim, 2000a), indeksi tarik: SNI 0436-1989 (Anonim, 2000b), indeks retak: SNI 14-14421998 (Anonim, 2000c), concora: SNI 140582-1989 (Anonim, 2000d), dan panjang putus serta kekuatan tarik (Anonim, 1983).

\section{Rancangan Percobaan dan Analisis Data Sifat Fisik Karton}

Rancangan percobaan yang digunakan adalah rancangan acak lengkap satu faktor, dan sebagai faktor (perlakuan) adalah: lembaran karton asal pulp TKKS 100\%, berikut bahan aditif (a1); lembaran asal campuran pulp TKKS (50\%) dengan sludge industri kertas (50\%), juga berikut bahan aditif (a2); dan kertas karton pembanding produksi industri karton rakyat dari campuran 50\% sludge dan 50\% kertas bekas, tanpa bahan aditif (a3). Setiap taraf dari perlakuan tersebut (a1, a2, dan a3) dilakukan sebanyak 5 kali ulangan. Respons yang diamati adalah data sifat fisik lembaran karton. Sekiranya pengaruh perlakuan nyata terhadap respons tersebut, dilakukan penelaahan lebih lanjut dengan uji Tukey atau uji jarak beda nyata jujur (BNJ). 


\section{HASIL DAN PEMBAHASAN}

\section{A. Sifat Pengolahan Pulp TKKS}

Data sifat pengolahan pulp TKKS yang mencakup rendemen, konsumsi alkali, dan waktu giling, dapat dilihat pada Tabel 1.

\section{Tabel 1. Sifat pengolahan pulp tandan kosong kelapa sawit (TKKS)} Table 1. Pulping properties of empty oil-palm bunches (EOPB)

\begin{tabular}{|l|c|c|}
\hline Sifat pengolahan (Pulping properties) ${ }^{*}$ ) & Nilai (Values) & Sb \\
\hline -Rendemen pulp (Pulp yield), \% & 60,17 & 2,819 \\
-Bilangan Kappa (Kappa No.) & 38,17 & 2,044 \\
-Konsumsi alkali (Alkali consumption), \% & 9,81 & 0,187 \\
-Waktu giling (Beating/refining duration) ${ }^{* *}$ ) & 125,49 & 0,2994 \\
\hline
\end{tabular}

Keterangan (Remarks) : *) Rata-rata dari 3 ulangan (Average of 3 replications); $\mathrm{Sb}=$ Simpangan baku (Standard deviation); dan/and ${ }^{* *}$ )Rata-rata waktu yang diperlukan untuk menggiling pulp TKKS sebanyak 1 gram berat kering pada Holander beater dan dilanjutkan di stone refiner untuk mencapai sekitar $400 \mathrm{ml} \mathrm{CSF}$ (Average duration required to fibrillate the EOPBpulp in Hollander beater and then in stone refiner to reach $400 \mathrm{ml}$ CSF)

Rata-rata rendemen pulp TKKS adalah sebesar 60,17\% yang mana masih terletak dalam selang rendemen yang umumnya diperoleh dari pengolahan pulp semikimia (60 - 75\%). Besarnya rata-rata bilangan kappa adalah 38,17 juga merupakan nilai yang umum diperoleh dari pengolahan pulp semikimia. Bilangan kappa yang relatif besar tersebut menunjukkan sisa kadar lignin yang masih tinggi dalam pulp TKKS. Kadar lignin yang tinggi dalam pembentukan lembaran pulp untuk karton diperlukan guna mempertinggi sifat kekakuannya. Konsumsi alkali yang diperoleh relatif besar (9.81\%) dibandingkan dengan konsentrasi alkali awal yang digunakan untuk pemasakan TKKS menjadi pulp (10\%). Kemungkinan hal ini disebabkan alkali selain dikonsumsi untuk melunakkan lignin, juga ikut dalam reaksi penyabunan sisa-sisa lemak/minyak yang masih terdapat dalam TKKS. Selanjutnya, rata-rata waktu giling pulp TKKS sebesar 125,49 menit dapat memberi indikasi untuk pertimbangan besarnya konsumsi energi khususnya pemakaian listrik atau bahan bakar dalam menggerakkan holander beater dan stone refiner.

\section{B. Sifat Kekuatan Fisik Lembaran Pulp TKKS untuk Karton}

Data sifat fisik kekuatan fisik pulp TKKS untuk karton yang diamati mencakup gramatur, tebal, kadar air, indeks retak, indeks sobek, indeks tarik, ring crush, dan panjang putus. Analisa keragaman menunjukkan bahwa pengaruh perlakuan (perbedaan macam lembaran pulp) berpengaruh nyata terhadap sifat kekuatan fisik tersebut (Tabel 2). Penelaahan lebih lanjut terhadap sifat kekuatan fisik tersebut dilakukan dengan menggunakan uji jarak beda nyata jujur dan selanjutnya diinterprestasikan dengan sistim skor (Tabel 3). 
Pembuatan dan kualitas karton dari ... (Han Roliadi \& Ridwan A. Pasaribu)

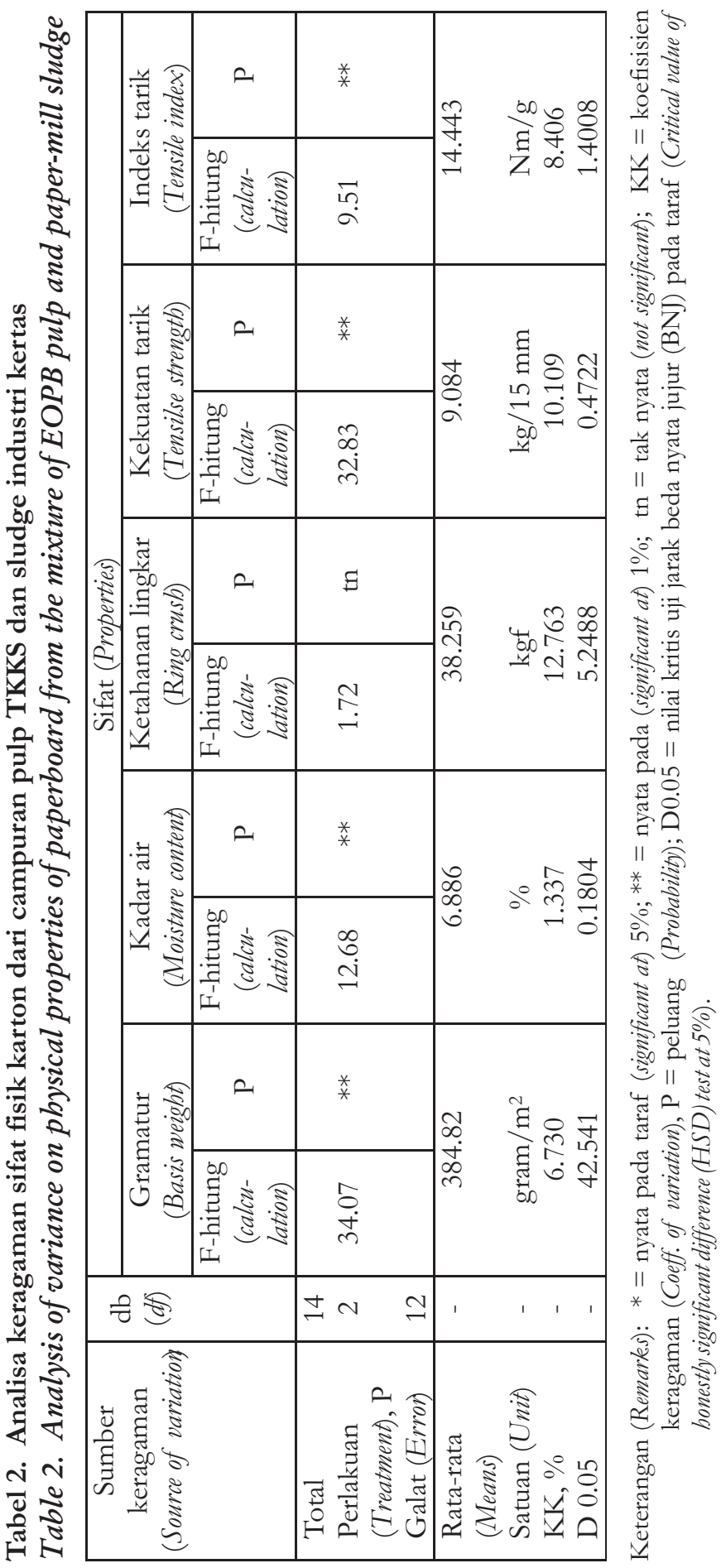


JURNAL Penelitian Hasil Hutan Vol. 24 No. 4, Agustus 2006: 323-337

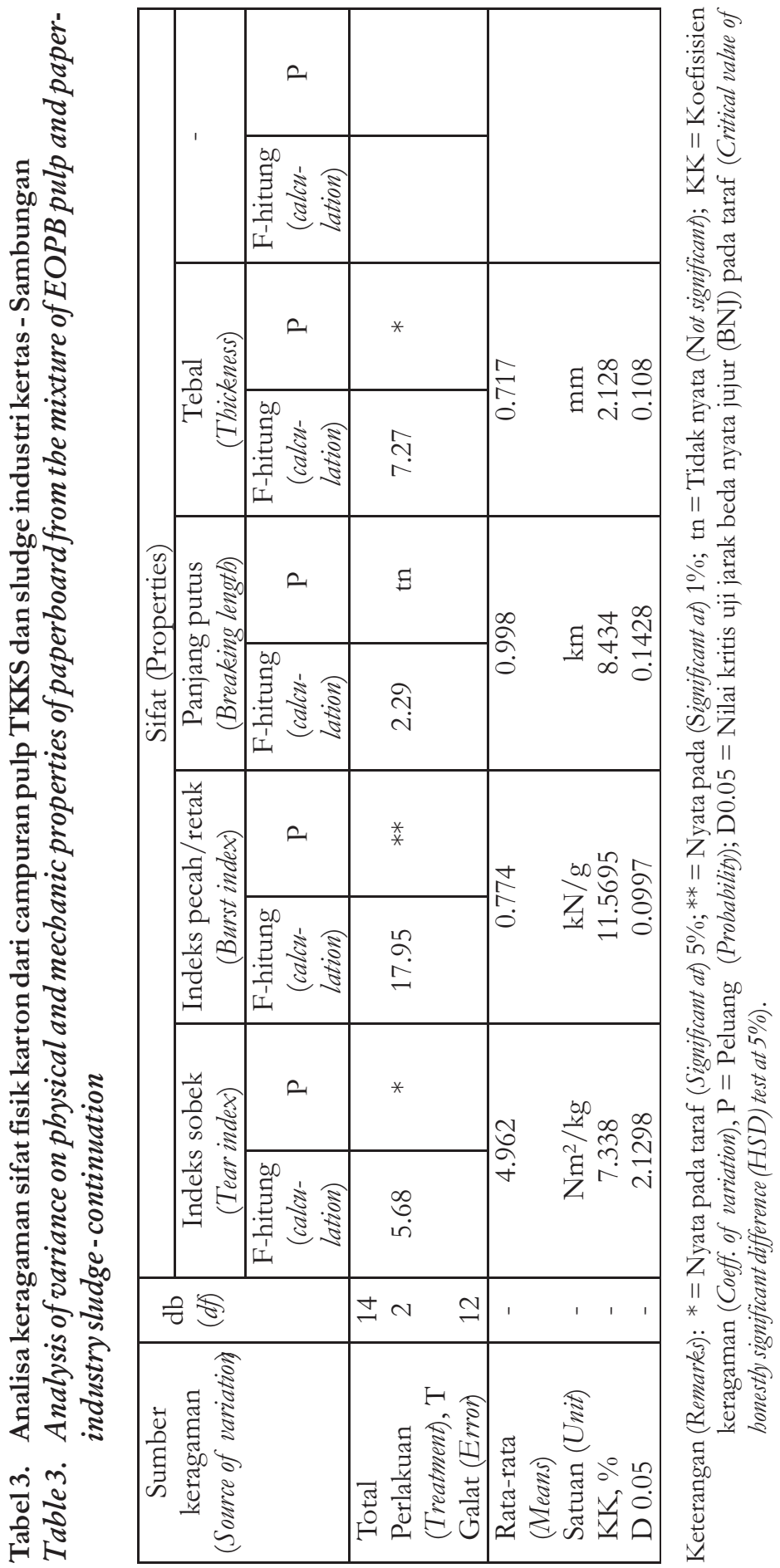


Secara keseluruhan gramatur atau bobot dasar karton dari pulp TKKS 100\% ataupun dari campurannya (pulp TKKS 50\% dengan sludge 50\% (Tabel 5) di atas target gramatur (300 - 350 gram per m2). Ini mungkin disebabkan adanya penambahan bahan aditif (perekat tapioka, pengisi kaolin, retensi alum, dan rosin size) pada suspensi pulp sebelum pembentukan lembaran. Selanjutnya, uji BNJ memunjukkan bahwa gramatur dan tebal karton dari pulp TKKS 100\% dan dari campuran pulp TKKS 50\% dengan sludge 50\% tidak berbeda nyata (Tabel 5). Ini mengindikasikan bahwa penggunaan bahan aditif (retensi alum, pengisi filler, perekat tapioka, dan rosin size) memberi efektifitas yang sama pada kekompakan ikatan dan anyaman serat sewaktu pembentukan lembaran karton baik dari pulp TKKS 100\% ataupun dari campurannya dengan sludge.

Ditinjau dari kadar air, ternyata kadar air lembaran karton asal 100\% pulp TKKS lebih rendah dari karton asal campuran pulp TKKS 50\% dengan sludge 50\%, dan juga lebih rendah dari kertas karton produksi industri rakyat yang terdiri dari campuran kertas bekas $50 \%$ dan sludge 50\% (Tabel 2 dan 3). Ini menunjukkan bahwa sifat sludge yang sifatnya lebih higroskopis (Anonim 1994), sehingga lembaran karton campuran tersebut lebih banyak menarik/mengikat uap air dari udara sekitarnya. Selanjutnya, lebih rendahnya kadar air karton asal campuran pulp TKKS 50\% dan sludge 50\% (menggunakan bahan aditif termasuk rosin size) dari pada karton produksi industri rakyat (dari campuran kertas bekas $50 \%$ dan sludge 50\%, tanpa aditif) menunjukkan bahwa rosin size yang bersifat water repellent dapat pula mengurangi sifat higroskopis karton yang dihasilkan.

Indeks retak, panjang putus, kekuatan tarik, dan ring crush karton dari pulp TKKS 100\% tidak berbeda nyata dengan karton dari campuran: pulp TKKS 50\% dan sludge 50\%. Akan tetapi dalam hal indeks sobek dan indeks tarik, nilai sifat fisik tersebut untuk karton asal pulp TKKS 100\% lebih tinggi dari pada karton asal campuran: pulp TKKS 50\% dan sludge $50 \%$. Ini mengindikasikan bahwa dalam sludge banyak mengandung serat-serat pendek dan partikel-partikel kecil bukan serat (antara lain: sisa bahan aditif) sehingga berpengaruh buruk pada kekompakan anyaman dan ikatan antar serat pada waktu pembentukan lembaran karton (Maybe, 1999).

Lebih lanjut, kekuatan tarik, indeks retak, dan indeks tarik lembaran karton dari pulp TKKS 100\% (dalam hal ini dengan bahan aditif) dan dari campuran: pulp TKKS 50\% dan sludge 50\% (juga dengan bahan aditif) lebih tinggi dari pada karton produksi industri rakyat yang terdiri dari campuran: kertas bekas 50\% dan sludge 50\% tanpa bahan aditif (Tabel 4 dan 5), sedangkan dalam panjang putus tidak berbeda nyata. Hal ini mengisyaratkan bahwa penambahan bahan aditif (retensi alum, pengisi kaolin, dan perekat tapioka ikut berperan positif pada kekompakan anyaman dan ikatan antar serat sebagaimana terjadi khususnya pada karton dari pulp TKKS 100\% dan campurannya (pulp TKKS 50\% dan sludge 50\%).

Secara keseluruhan dapat dikatakan bahwa sifat fisik karton dari pulp TKKS 100\% ataupun dari campurannya (pulp TKKS 50\% dengan sludge 50\%) lebih baik dari pada karton produksi industri rakyat, hal ini berdasarkan pada nilai skor total hasil manipulasi uji BNJ (Tabel 2 dan 3), yaitu berturut-turut dengan skor 35, 32, dan 28. Juga sifat karton asal pulp TKKS 100\% (menggunakan aditif kaolin, alum, tapioka, dan rosin size) terutama dalam hal indeks sobek dan indeks retak lebih baik dari pada karton juga asal pulp TKKS 100\% dengan menggunakan aditif dalam jumlah yang sama, tetapi tanpa rosin size (Roliadi dan Pasaribu, 2004). Ini mengindikasikan bahwa penggunaan rosin size selain bersifat water repellent ikut pula berperan memperbaiki sifat fisik lembaran karton. Selanjutnya, sifat fisik karton tersebut 
JURNAL Penelitian Hasil Hutan Vol. 24 No. 4, Agustus 2006: 323-337

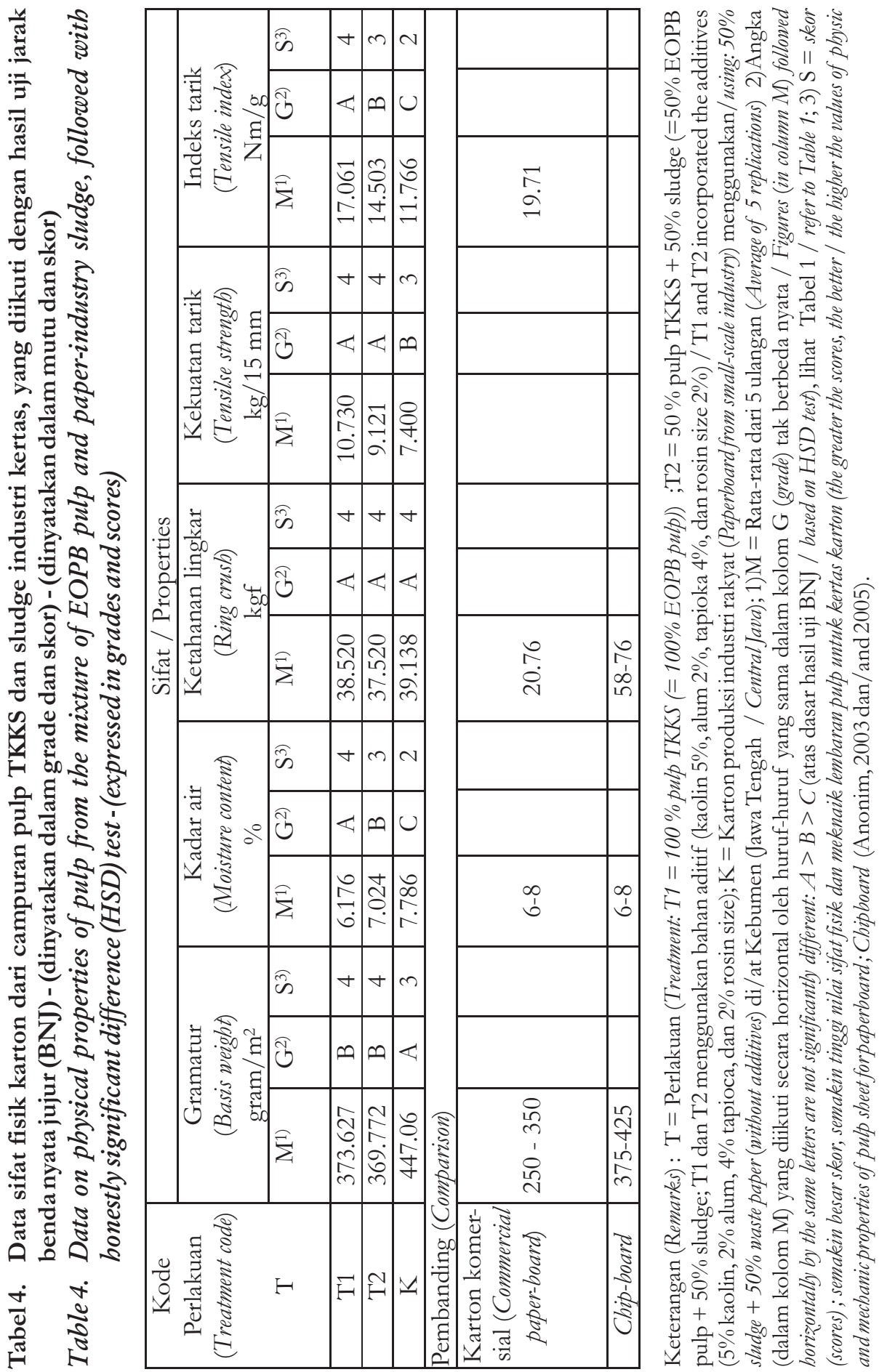




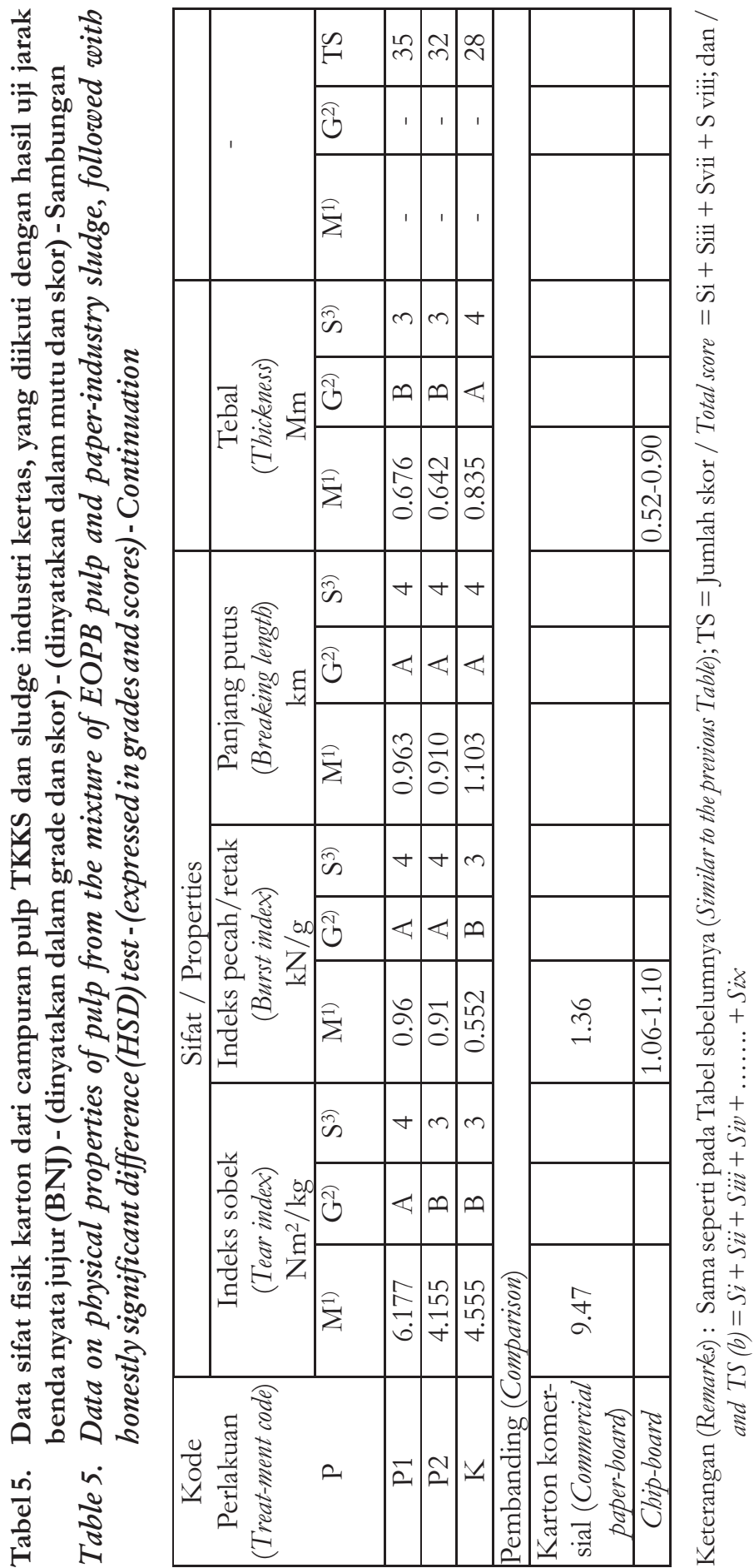


(dari pulp TKKS 100\% dan dari campuran pulp TKKS 50\% dengan sludge 50\%, masingdiberi aditif kaolin, alum, tapioka, dan rosin size) memenuhi persyaratan kualitas karton komersial dan karton jenis chipboard, kecuali dalam hal indeks tarik, indeks retak, dan indeks sobek. Diharapkan kekurangan tersebut dapat diperbaiki dengan lebih banyak penambahan rosin size dan/atau perekat tapioka.

Rendemen lembaran karton asal pulp TKKS 100\% yang dibentuk di pabrik karton rakyat berdasarkan berat bahan serat yang masuk ke penggilingan (Hollander beater) dan setelah mengalami penggilingan dilanjutkan dengan pengeringan dan calendering adalah sebesar $84.41 \%$ (Tabel 4). Lebih lanjut setelah mengalami pemotongan dan pengepakan, rendemennya mencapai $70.74 \%$. Untuk lembaran karton asal campuran yang terdiri dari pulp TKKS 50\% dan sludge 50\%, besar rendemen setelah mengalami penggilingan, pengeringan, dan calendering adalah $81.25 \%$, sedangkan setelah mengalami pemotongan dan pengepakan, rendemennya mencapai $68.16 \%$. Secara keseluruhan terrnyata rendemen lembaran karton asal campuran pulp TKKS dengan sludge (50\%: 50\%) lebih rendah dari rendemen asal pulp TKKS murni (100\%). Hal ini memberi indikasi pula bahwa dalam sludge selain terdapat serat pendek dan fines, juga terdapat partikel-partikel kecil bukan serat (Mabee, 1999). Rendemen lembaran karton baik asal pulp TKKS murni ataupun asal campurannya ternyata masih dalam selang rendemen karton yang lazim diperoleh oleh industri karton karton (PT "DS") yang menggunakan bahan baku campuran sludge 50\% dan kertas bekas 50\% (tanpa bahan aditif) yaitu: yaitu 80 - 85\% (setelah penggilingan, pengeringan, dan calendering).

Tabel6. Rendemen kertas karton yang dibentuk dari pulp TKKS $100 \%$ dan dari campuran pulp TKKS dengan sludge industri kertas $(50 \%: 50 \%)$, yang dilakukan di pabrik karton rakyat (PT "DS")

Table 6. Yield of paperboard from 100\% EOPB pulp, and from the mixture of $50 \%$ EOPB pulp and 50\% paper-mill sludge, formed at small-scale industry (PT "DS")

\begin{tabular}{|c|c|c|c|}
\hline \multirow[b]{2}{*}{ No } & \multirow[b]{2}{*}{$\begin{array}{l}\text { Macam bahan serat } \\
\text { (Kind of fiber stock) }\end{array}$} & \multicolumn{2}{|c|}{ Rendemen (Yield), $\%{ }^{1)}$} \\
\hline & & $\begin{array}{l}\text { Setelah penggilingan } \\
\text { di Holander beater } \\
\text { dilanjutkan dengan } \\
\text { pengeringan, dan } \\
\text { calendering (After } \\
\text { beating, sun-drying, and } \\
\text { calendering) }\end{array}$ & $\begin{array}{c}\text { Setelah } \\
\text { pemotongan, dan } \\
\text { pengepakan } \\
\text { (After cutting and } \\
\text { packaging) }\end{array}$ \\
\hline 1 & $\begin{array}{l}\text { Pulp TKKS } 100 \% \text { (100\% EOPB } \\
\text { pulp) } \\
\text { Campuran dari: pulp TKKS } 50 \% \\
+ \text { sludge } 50 \% \text { (Mixture of: } 50 \% \\
\text { EOPB pulp }+50 \% \text { sludge) }\end{array}$ & $\begin{array}{l}84.41 \\
81.25\end{array}$ & $\begin{array}{l}70.74 \\
68.16\end{array}$ \\
\hline
\end{tabular}

${ }^{1)}$ Berdasarkan berat kering bahan baku (termasuk bahan serat, dan bahan aditif : alum, kaolin, dan perekat tapioka) pada saat sebelum penggilingan (Based on dry weight of stock (including fiber stuffs, and additives: alum, kaolin, and tapioca) at the instant before beating) 


\section{KESIMPULAN DAN SARAN}

\section{A. Kesimpulan}

Dari hasil percobaan pembuatan karton dari pulp tandan kosong kelapa sawit (TKKS) 100\% (dengan bahan aditif: alum 5\%, kaolin 2\%, perekat tapioka 4\%, dan rosin size $2 \%$ ) dan dari campuran pulp TKKS 50\% yang dicampur dengan sludge industri kertas (50\%) juga memakai bahan aditif (dengan macam dan jumlah yang sama) diperoleh beberapa hal sebagai berikut:

Rendemen rata-rata pulp TKKS yang diolah dengan proses semi kimia soda panas dalam ketel pemasak hasil rekayasa Pusat Litbang Teknologi Hasil Hutan (Bogor) sebesar $60.17 \%$ di mana masih terletak dalam selang rendemen yang umum hasil pengolahan pulp secara semi kimia (60 - 75\%). Juga bilangan kappa pulp TKKS (38.17) terletak dalam nilai yang umum pada pulp untuk karton $(\geq 35)$. Konsumsi alkali selama pengolahan pulp TKKS mencapai $9.81 \%$ hampir mendekati nilai konsentrasi awal alkali yang digunakan pada pemasakan TKKS $(10 \%)$.

Pulp TKKS tersebut dibentuk menjadi lembaran karton di industri karton rakyat (PT "DS" di Kebumen, Jawa Tengah), lalu diperiksa gramatur, tebal, dan sifat fisiknya. Gramatur dan tebal lembaran karton dari pulp TKKS 100\% dan dari campurannya (pulp TKKS 50\%, sludge $25 \%$, dan kertas bekas $25 \%$ ) tidak saling berbeda, dan keduanya lebih rendah dari gramatur dan tebal karton produksi industri rakyat di mana terdiri dari campuran kertas bekas 50\% dan sludge 50\% (tanpa penggunaan bahan aditif). Walaupun demikian, sifat fisik lembaran karton (terutama dalam hal kekuatan tarik, indeks tarik, dan indeks retak) asal pulp TKKS 100\% dan asal campurannya tersebut lebih tinggi dari pada karton produksi industri rakyat. Lebih lanjut, sifat fisik karton dari pulp TKKS 100\% lebih tinggi dari campurannya tersebut (pulp TKKS 50\% dan sludge 50\%). Hasil tersebut mengindikasikan bahwa penggunaan sludge dapat menurunkan sifat fisik lembaran karton yang dihasilkan.

Hal lain yang menarik adalah kadar air karton asal pulp TKKS 100\% (menggunakan bahan aditif: kaolin, alum, tapioka, dan rosin size) lebih rendah dari pada kadar air karton asal pulp TKKS 100\% (menggunakan bahan aditif dengan macam dan jumlah yang sama tetapi tanpa rosin size). Demikian pula, sifat fisik karton asal pulp TKKS 100\% (menggunakan bahan aditif: kaolin, alum, tapioka, dan rosin size) lebih tinggi dari pada yang tanpa menggunakan rosin size. Ini mengindikasikan bahwa rosin size selain bersifat water repellent juga dapat memperbaiki sifat fisik karton.

Selanjutnya, sifat fisik karton dari pulp TKKS (yang dicampur dengan sludge) yang lebih tinggi dari sifat karton produksi industri rakyat, mengisyaratkan bahwa pulp TKKS berikut penggunaan bahan aditif (alum, kaolin, perekat tapioka, dan rosin size) dapat digunakan sebagai substitusi atau alternatif penggunaan kertas bekas yang selama ini dipakai sebagai bahan baku industri karton rakyat di mana semakin sulit di dapat, dan selama ini pula produksi kartonnya dibuat dari campuran kertas bekas dan sludge, tetapi tanpa bahan aditif.

Lebih lanjut, hal yang memberi isyarat baik tersebut juga dengan memperhatikan bahwa rendemen karton dari pulp TKKS 100\% dan dari campurannya (pulp TKKS 50\% dan sludge $50 \%$ ) ternyata masih dalam selang rendemen karton yang lazim diperoleh di industri karton rakyat tersebut $(80-85 \%)$. 
Dibandingkan dengan persyaratan kualitas karton komersial dan jenis chipboard, sifat fisik karton dari pulp TKKS $100 \%$ dan dari campurannya (pulp TKKS 50\% dan sludge 50\%) memenuhi syarat, kecuali dalam hal indeks retak, indeks sobek, dan indeks tarik.

\section{B. Saran}

Sebagai saran, sifat fisik yang tidak memenuhi syarat tersebut (indeks retak, indeks sobek, dan indeks tarik) diharapkan dapat diatasi dengan lebih banyak pemakaian perekat tapioka dan/atau rosin size pada pembuatan karton dari campuran pulp TKKS dan sludge.

\section{DAFTAR PUSTAKA}

Anonim. 1972. Testing methods, Recommended practices, Specification of the Technical Assosiation of the Pulp and Paper Industries (TAPPI). New York

. 1981. Standard Industri Indonesia (SII) untuk pulp dan kertas. Departemen Perindustrian, Jakarta.

1983. Technical Association of the Pulp and Paper Industry (TAPPI)'s test method.

TAPPI Press. Atlanta, Georgia

. 1984. Standar Industri Indonesia (SII) untuk pulp dan kertas. SII 0435-81, SII 0436-

81, SII 0529-81, SII 0531-81 Departemen Perindustrian, Jakarta.

.1993. Potensi kelapa sawit dan limbah lignoselulosa kelapa sawit. Biro Pusat Statistik, Jakarta.

. 1994. Sludge incineration technology create alternative to landfilling. Sludge Technology, pg. 6-7

.1998a. Project proposal: Pulp and paper from empty palm bunches. PT. Triskisatrya

Daya Pratama PT. Chatama Agro Indofin. Jakarta

1998b. Menuai devisa dengan limbah kelapa sawit. Harian Kompas (Jakarta), 18

Maret 1998

.2002. Spesifikasi kertas karton jenis chipboard menurut SNI 14-6592-2002

2000a. Cara uji indeks sobek lembaran pulp dan kertas. Badan Standardisasi Nasional. Jakarta. SNI 0435-89.

2000b. Cara uji indeks tarik lembaran pulp dan kertas. Badan Standardisasi

Nasional. Jakarta. SNI 0436-89.

2000c. Cara uji indeks retak lembaran pulp dan kertas. Badan Standardisasi Nasional. Jakarta. SNI 14-1442-1998.

. 2000d. Cara uji ketahanan tekan (concora) lembaran pulp dan kertas. Badan Standardisasi Nasional. Jakarta. SNI 14-0582-1989. 
. 2003. Indonesian pulp and paper industry. Directory 2003. Indonesian Pulp and Paper Association, Jakarta Indonesia. 2004

2004. Industri hilir CPO perlu merek produk. Harian Kompas (Jakarta), 7 Oktober .2005. Standar kualitas karton jenis chipboard. PT Kertas Bekasi Teguh, Jakarta 2006. Produksi CPO bisa stagnan. Harian Kompas (Jakarta), 22 Mei 2006.

Mabee, W. 1999. Comparative study on the chemical composition of paper-mill sludge. Ph. D Candidate. Website: www.chem-eng.utoronto.ca/-pphone/Research/ Othermabee.html. Diakses 5 Maret 2002.

Martawijaya, A. dan P. Sutigno. 1990. Prospek dan permasalahan industri perkayuan. Proseding Diskusi Industri Perkayuan di Jakarta, 29-30 April 1990. Pusat Litbang Hasil Hutan dan Sosial Ekonomi Kehutanan, Bogor.

Pasaribu, R.A. dan Silitonga. 1977. Percobaan pengolahan kayu daun lebar campuran sebagai bahan baku pulp kertas. Laporan No. 100. Lembaga Penelitian Hasil Hutan, Bogor.

R.M. Siagian, H. Roliadi. 1990. Kajian pemanfaatan limbah kayu untuk pulp kertas dan papan serat. Makalah Penunjang Disampaikan Pada Seminar Teknologi Perkayuan, tanggal 24 Januari, 1990, Jakarta

dan I. Winarni. 2002. Pemanfaatan tandan kosong kelapa sawit sebagai bahan substitusi kayu pulp untuk kertas korugating medium. Prosiding Seminar Nasional V MAPEKI di Bogor, tanggal 30 Agustus 1 September 2002 : 447 492. Kerjasama Masyarakat Peneliti Kayu Indonesia (MAPEKI) dengan Puslitbang Teknologi Hasil Hutan, Bogor

Rina S.S., S. Purwanti, H. Hardiani, dan S. Surachman, 2002. Pengaruh kompos dan limbah lumpur IPAL industri kertas terhadap tanaman dan tanah. Prosiding Seminar Teknologi Selulosa Balai Besar, tanggal 12 Desember 2004, Penelitian dan Pengembangan Industri Selulosa, Bandung.

Roliadi, H. dan R.A. Pasaribu. 2004. Teknologi pembuatan pulp tandan kosong kelapa sawit untuk karton. Laporan Hasil Penelitian Sumber Dana DIK-S DR Tahun 2004. Departemen Kehutanan, Badan Penelitian dan Pengembangan Kehutanan, Pusat Penelitian dan Pengembangan Teknologi Hasil Hutan. Bogor. 